\title{
SINEMATOGRAFI WAYANG: \\ PERSOALAN TRANSMEDIA SENI PERTUNJUKAN TRADISIONAL DALAM PROGRAM TAYANGAN TELEVISI
}

\author{
Arif Eko Suprihono \\ Jurusan Televisi, Fakultas Seni Media Rekam \\ Institut Seni Indonesia Yogyakarta \\ Jalan Parangtritis Km 6,5 Sewon, Yogyakarta \\ Pelaku Experiencial Learning, mengelola kegiatan di http://wonosalamtraining.com. \\ No.Hp.: 08562567879; E-mail: aesuprihono@gmail.com.
}

\begin{abstract}
ABSTRAK
Merujuk pada proses penelitian delapan tahun terakhir dan melihat hasil kerja Penelitian Hibah Bersaing dan Penelitian Produk Terapan, terungkap kompleksitas pengelolaan kegiatan seni pertunjukan tradisional di masyarakat. Berkait erat dengan budaya industri televisi, terbentang peluang sekaligus ancaman serius bagi eksistensi seni tradisi. Berdasarkan hasil kerja penelitian dalam rencana makro disarankan urgensi tindakan konstruktif dan sistematis kepada para pekerja seni untuk mengantisipasi benturan kepentingan industri pertelevisian Indonesia dengan pengelolaan seni pertunjukan tradisional. Persoalan sinematografi seni tradisional membahas proses dialektika kreatif dan mengarah pada pemikiran, tindakan, dan produk budaya dengan menyadari kerangka perubahan dan penyesuaian kultural. Diyakini, bahwa kesenian tradisi memiliki nilai luhur, kearifan lokal, identitas karakter masyarakat, nilai kebhinnekaan dan keunggulan, serta kekhasan suku bangsa Indonesia, yang dianggap berbeda bila dibandingkan dengan bangsa-bangsa lain di dunia.
\end{abstract}

Kata kunci: sinematografi wayang, pertunjukan tradisional di televisi, kajian budaya

\begin{abstract}
Cinematogprahy of Wayang: A Case of Traditional Performing Arts Transmedia on Television Programs. Referring to the research process in the last eight year and looking at the work of the Competitive Grant Research and Applied Product Research, the complexity of managing traditional performing arts activities in the community was revealed. Closely related to the culture of the television industry, opportunities and serious threats appose in terms of the existence of traditional arts. The result of a research work suggests the urgency of conducting a constructive and systematic action to the arts workers to anticipate the conflicting interests of the Indonesian television with the management of traditional performing arts. The issue of traditional art cinematography refers to the process of creative dialectics leading to thoughts, actions, and cultural products by being aware of cultural changes and adjustment of frameworks. It is believed, that traditional arts have noble values, local wisdom, character identity of the community, value of diversity and excellence, as well as the uniqueness of Indonesian tribes, which were considered more divergent than the other nations from the world.
\end{abstract}

Keywords: cinematography of wayang, traditional performing arts on television, cultural 


\section{PENDAHULUAN}

Artikel jurnal ini disusun sebagai upaya langkah penyempurnaan dan kelanjutan kerja penelitian "Cinematography Seni Pertunjukan Tradisional Indonesia dalam Program Tayangan Televisi". Proses kerja penelitian dilatarbelakangi oleh fakta lapangan, bahwa dalam materi tayang program televisi terlihat kualitas kemasan seni tradisional Nusantara kurang optimal(Suprihono, 2014). Ukuran optimal sangat terbuka untuk diperdebatkan lebih panjang dan mendalam, tetapi telah ditemukan indikator awal. Adalah sebuah faktualitas, bahwa melihat sajian seni tradisi melalui televisi tidak lebih mengesankan jika dibanding melihat langsung di panggung pergelaran. Fakta lain, para pekerja kreatif industri pertelevisian tidak pernah berhenti untuk melakukan eksplorasi dan penemuan formula kemasan seni pertunjukan melalui media audiovisual. Di sisi lain, eksistensi seni pertunjukan menyadarkan bahwa tidak terhitung jumlah tradisi kesenian daerah dan identitas budaya lokal bernuansa kesukubangsaan di seluruh wilayah Indonesia. Sayangnya, terlihat banyak sekali potensi seni pertunjukan tradisional Nusantara tidak dapat ditangkap dan diungkap secara lengkap dalam program penyiaran televisi. Pantas dipertanyakan, mengapa hanya model sajian seni pertunjukan tertentu, dihadapkan dengan seleksi karakteristik format acara industri televisi, para pekerja kreatif televisi merasa berhasil memilahkan dan memilih sejumlah kecil seni panggung sebagai materi program mengisi jam siaran. Seperti pendapat Curran, ada dua pandangan berbeda tentang kekuatan media, yakni mendominasi audiens di satu sisi, sementara lainnya hubungan terbalik. Namun, kedua pandangan itu bermasalah, paling tidak karena mereka didasarkan pada metodologi kurang tepat (Curran, 2002).
Pemahaman terhadapkarakteristiksajian program televisi antara lain: pengelompokan program news - non news atau program fiction and non fiction (Naratama, 2004); kejelasan segmentasi pasar/penonton, durasi tayangan singkat dan fleksibel untuk jeda-jeda/ insert informasi, bisa disaksikan sambil lalu, ditayangkan selintas, dan tidak harus dilihat secara terfokus, bersifat menghibur, dan bagi media elektronik komersial lebih menekankan pada upaya menarik minat banyak sponsor. Menyelidiki budaya pertunjukan di layar televisi sebagai asumsi tradisional tidak reflektif dalam upaya menjelaskan nilai "kekuatan" klise dan mistifikasi seperti "keajaiban" teater langsung, "energi" yang konon ada antara pemain dan penonton dalam sebuah pertunjukan. Komunitas pertunjukan langsung sering dikatakan diciptakan di antara para pemain dan penonton, konsep seperti ini memang memiliki nilai bagi penampil dan pendukung pertunjukan langsung (Auslander, 2008).

Ditemukenali fakta bahwa seni panggung disajikan sebagai latar belakang penelitian cinematography seni pertunjukan tradisional Indonesia dan diungkap secara ringkas sebagai studi kasus dalam artikel ini, adalah pergeseran estetika seni pertunjukan (Suprihono, 2007) wayang kulit, diduga jauh terombak dan meninggalkan 'tradisi pergelaran' dengan pola pementasan studio televisi. Wujud sajian pementasan wayang di layar kaca dengan kekhasan dan gaya glamornya terbukti memengaruhi selera pemirsa.

Pola pikir masyarakat secara revolusif berubah pada saat mengapresiasi pergelaran wayang dengan formula pemanggungan televisi. Berikut ini beberapa fakta visual dipahami penikmat wayang kulit. 


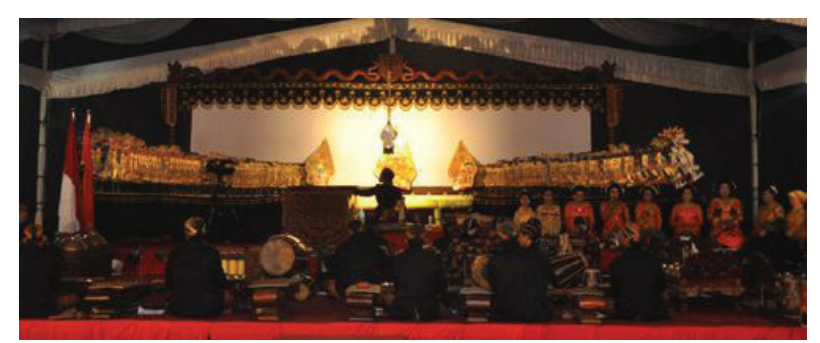

Gambar 1 Visualisasi setting pergelaran wayang dengan penataan 'baru'

(1) Sisi pemanggungan, setting pergelaran wayang diekploitasi secara berlebihan seperti panjang layar (geber) hampir tiga kali lipat ukuran geber "tradisi" pementasan di masyarakat.

(2) Tempat duduk para vokalis perempuan (sindhen) tidak lagi berada di depan pengendang, tetapi didudukkan di sebelah kanan dalang berhadapan dengan para penabuh gamelan. Para sindhen tidak saja sekadar sebagai vokalis pendukung dalam rangkaian musik pengiring pergelaran, tetapi jauh lebih terekspos secara auditif dan visual, sebagai tokoh lain di depan layar simpingan wayang bagian kanan dalang.

(3) Peran sindhen

dalam mempertunjukkan kualitas suara dan kecantikan tampilan diri terlihat dalam dominasi adegan limbukan, yang sengaja dipakai sebagai 'sekuen' penghibur dan melepaskan diri dari kungkungan alur cerita.

(4) Belum lagi adegan tambahan yang diduga dapat "merusak" estetika tradisional wayang, yaitu kehadiran tokoh-tokoh komedian seolah (wajar dan mampu) mengambil alih superioritas dan otonomi dalang di atas panggung. Substitusi peran antara dalang dan tamu penghibur sebagai tokoh utama di panggung wayang sangat tidak sejalan dengan filosofi pedalangan "klasik". Anehnya, masyarakat sangat menyenangi hasil kerja kreatif awak media televisi ini. Bahkan, seolah mereka kehilangan selera nonton wayang jika adegan limbukan ini tanpa kehadiran bintang tamu.

(5) Orientasi kehadiran penonton tidak lagi berada di belakang layar, melihat pertunjukan dari sisi bayangan figur wayang, berpindah 180 derajat dan lebih melihat pada tatanan konstruksi seni animasi langsung. Estetika wayang menjadi lebih pada tampilan sajian teknis pementasan, bukan lagi menikmati seni animasi figur menggunakan sumber cahaya kilatan blencong di balik geber pentas.

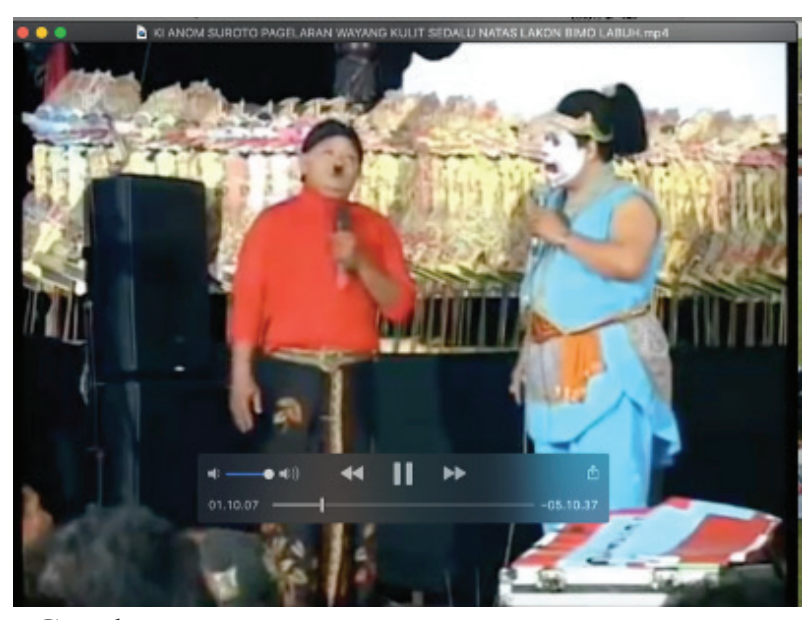

Gambar 2 Adegan limbukan, waktu para tokoh 'lain' mengendalikan pergelaran wayang. 
Diasumsikan dalam penelitian ini bahwa hampir semua perubahan model pementasan wayang di masyarakat saat ini merupakan akibat bentuk reaktif dari hasil kreasi pekerja multimedia, diawali dari tuntutan penempatan sejumlah banyak kamera televisi pada saat harus merekam ataupun menyulihwujudkan sajian pertunjukan wayang panggung dalam format program tayang cinematik. Secara teoretik, penempatan kamera merupakan salah satu komponen pembentuk cinematography (Suprihono, 2014). Akibat eksotisme gerak kamera dan tujuan menyajikan detail framing bahasa gambar secara sepihak telah memutarbalikkan tradisi pementasan wayang. Salah satu akibat adalah terbentuknya perilaku masyarakat pada saat hadir melihat wayang kulit, saat ini tidak lagi mengutamakan apresiasi dari balik layar dengan melihat efek bayangan figur wayang, tetapi secara terbalik lebih senang melihat perilaku terampil dalang dalam mengolah gerak boneka wayang. Hal demikian tampaknya sederhana sebagai sebuah perilaku apresiatif, tetapi secara kultural memiliki pola pikir dan pandang bertolak belakang jika dibandingkan dengan 'tradisi nonton' pergelaran wayang kulit.

Pemahaman wacana estetika di Indonesia ada kecenderungan meminggirkan para pemikir lokal (Hidayat, 2014). Perubahan setting pertunjukan wayang akibat tuntutan kreativitas pekerja media televisi seolah meminggirkan estetika tradisi, dengan berbagai kompleksitas estetiknya.

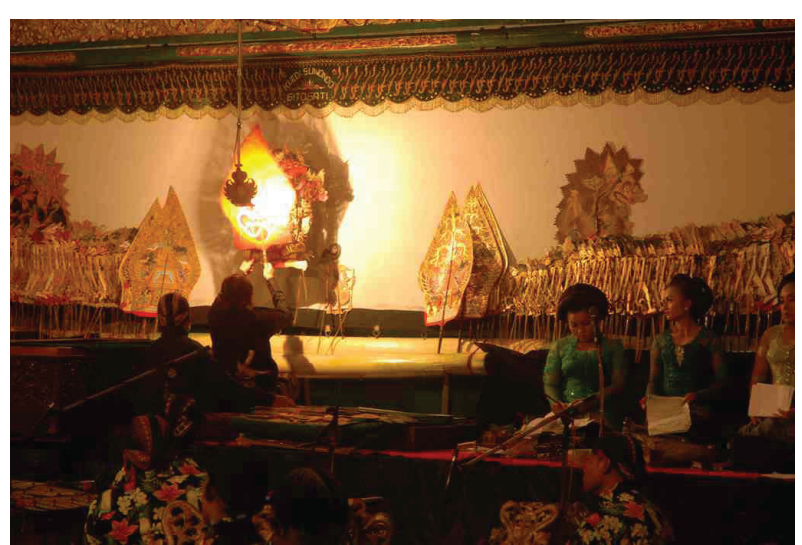

Gambar 3 Pementasan wayang kulit di Balai Pelestarian Sejarah dan Nilai Tradisional Yogyakarta, 9 Oktober 2011 oleh Ki Edi Suwondo dengan Lakon Banjaran Bisma.

Koleksi foto: Arif Eko Suprihono, 2011.

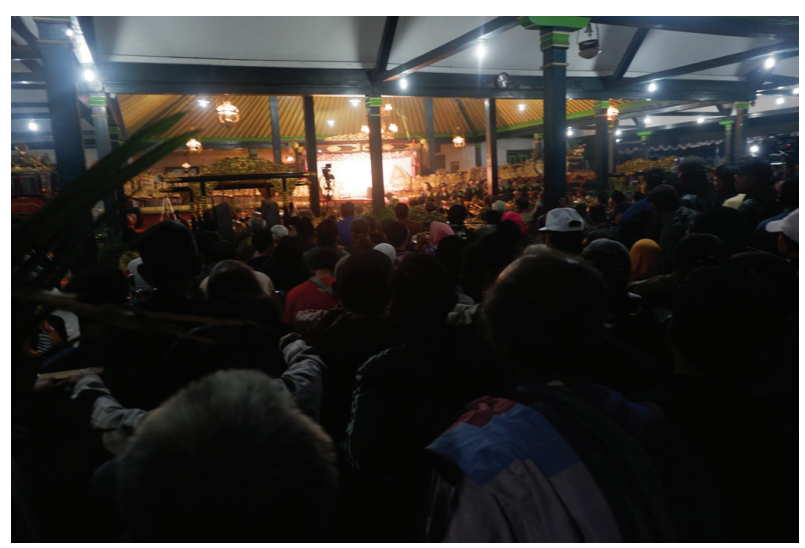

Gambar 4 Pementasan wayang kulit di Pendapa GBPH Yudaningrat, kompleks Kraton Yogyakarta, dengan lakon Pendawa Boyong, oleh Ki Dalang Seno Nugroho, September 2019. Koleksi foto: Arif Eko Suprihono, 2019.

\section{Masalah Sinematografi Wayang}

Artikel ini disusun sebagai bentuk ringkas dari proses penelitian sinematografi wayang dengan tujuan mempelajari potensi wayang kulit Jawa dengan lebih tersistematisasi dan mencari pencerahan kultural untuk mengangkat persoalan penelitian. Dalam proses kerja penelitian ini dihadapkan pada etika kerja ilmiah didasarkan pada tujuan penelitian, yaitu:

1. mengidentifikasi model penerapan sinematografi seni pertunjukan tradisional Indonesia khususnya pementasan wayang kulit Jawa dalam format program tayangan televisi. Identifikasi mencakup evaluasi 
kelebihan, kekurangan, dan peluang kemungkinan dikenali dengan mudah sebagai potensi seni pertunjukan media televisi (Suprihono, 2007).

2. mengidentifikasi kompleksitas potensi wayang kulit Jawa di lingkungan aktivitas masyarakat, dengan melakukan pencermatan adegan-adegan jejer, untuk mengenali narasi-narasi visual auditif yang dilakukan oleh dalang. Kearifan lokal dan karakteristik wayang kulit Jawa perlu diformulasikan dengan lebih jelas agar lebih banyak dikenali oleh para pelaku industri media televisi. Kompleksitas pergelaran wayang juga berpengaruh pada interaksi penonton. Bahwa kehadiran penonton di lingkungan pergelaran sangat dipengaruhi oleh karakteristik jenis panggung dapat dipahami dengan mudah. Pada dasarnya penyajian seni pertunjukan dilakukan dalam banyak pilihan panggung, antara lain bentuk arena, proscenium, dan bahkan pendopo. Dalam konteks demikian, karakteristik masing-masing panggung menjadi sangat berarti dalam kehadiran penonton (Suprihono, 2007).

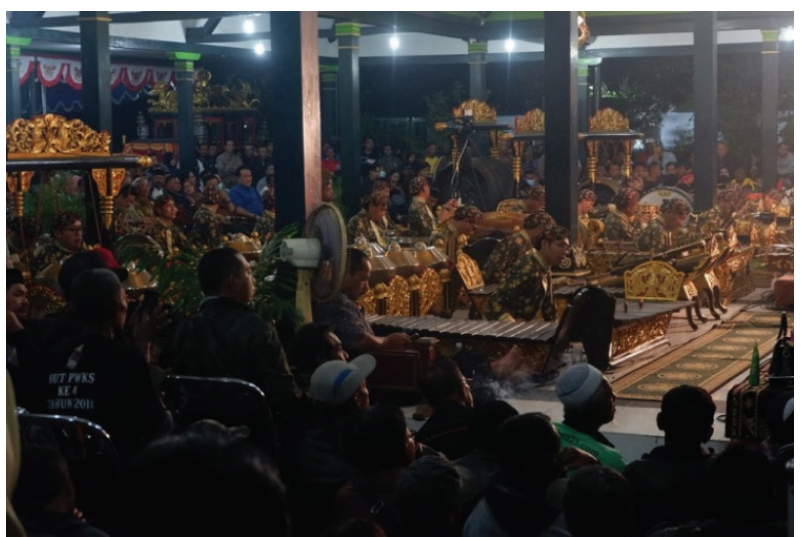

Gambar 5 Posisi penonton VIP di belakang dalang. Setting model pertunjukan studio televisi memberikan indikasi perubahan selera estetis masyarakat dalam menanggapi model pergelaran wayang. (Koleksi Arif E. Suprihono, 2019).

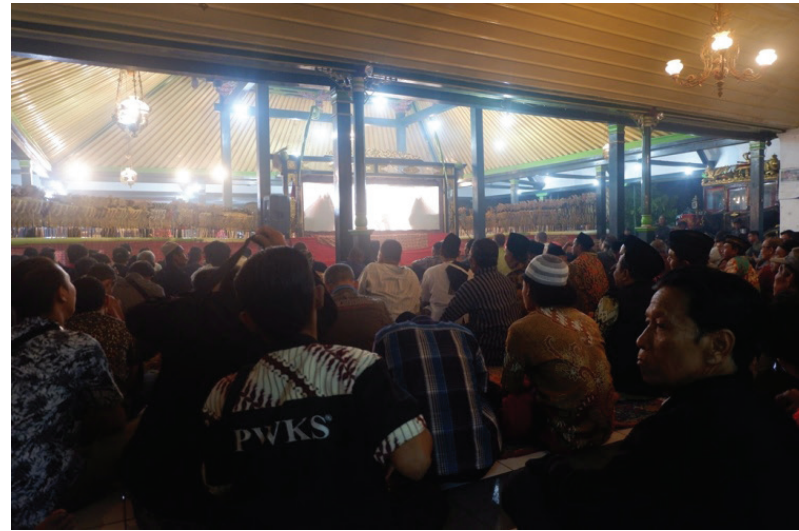

Gambar 6 Posisi penonton di balik layar pertunjukan. Koleksi: Arif E. Suprihono, 2019.

3. menemukan kendala transformatif model panggung dalam proses kerja kreatif menjadi kemasan tayang. Penjabaran kendala kreatiftransmedia diperjelas dalam formula sinematografi wayang kulit Jawa agar interaksi seni pertunjukan tradisional Indonesia dan dunia penyiaran publik dapat bersinergi dengan baik. Penemuan dan formulasi model sinematografi ini dapat dikaji secara berkelanjutan untuk karakter budaya penyiaran pada masa datang.

Penelitian sinematografi wayang berusaha untuk menemukan jawab atas pertanyaan-pertanyaan berikut ini.

1 Bagaimana formulasi sinematografi seni tradisi dalam mengatasi kendala pengelolaan industri kreatif televisi pada saat mengangkat seni pertunjukan tradisional sebagai materi tayang?

2 Bagaimana interaksi kultural antara pelaku wayang kulit Jawa dan pelaku industri kreatif pertelevisian dilakukan untuk mengemas seni pertunjukan tradisional?

3 Bagaimana adegan jejeran wayang kulit jawa dapat ditransmediakan menggunakan formula sinematografi 
tertentu agar dapat mengoptimalisasikan penayangan wayang di televisi?

4 Bagaimana kerja kreatif transmedia dapat menjamin otentisitas nilai kultural wayang kulit Jawa pada masa mendatang?

\section{Kajian Pustaka Pendukung}

Penelitian ini sengaja mengangkat dan mendalami istilah sinematografi dibandingkan dengan videografi. Peneliti menyadari sepenuhnya, bahwa tujuan dari pembahasan dua istilah ini bermuara pada teknik mengontrol elemen-elemen penciptaan gambar untuk mendapatkan struktur estetis yang memiliki kekhasan dalam satu rangkaian produksi. Upaya mengontrol dan mengendalikan elemenelemen penciptaan gambar ini dimaksudkan untuk mengembangkan cerita yang sedang disajikan di depan penonton. Istilah-istilah seperti framing, camera movement, staging of action, dan lighting control adalah beberapa dari sedemikian banyak istilah yang dipergunakan oleh pengarah acara dan director of photography dalam mewujudkan kreativitasnya dengan kamera.

Sinematografi dibentuk dari kata kinema (bahasa Yunani) berarti gerakan dan graphein dimaknai secara bebas dengan melukis, merekam. Sebagai jenis aktivitas fotografi, sinematografi merupakan produk motion photography. Oleh karena aktivitas dan produknya, sinematografi memiliki tambahan kesulitan teknik mencakup gerakan kamera dan kemungkinan banyak kreativitas disebabkan oleh variasi gerakan itu.

\section{Liveness Performance in a Mediatized}

\section{Culture}

Tulisan Auslander (2008) mengenai dominasi budaya televisi dan produksinya.
Dengan menyetujui pendapat Cecilia Tichi, diargumentasikan bahwa televisi tidak lagi dapat dilihat hanya sebagai salah satu unsur lembaga di lingkungan budaya, tetapi televisi seharusnya dilihat sebagai lingkungan lembaga otonom. Dengan kata lain, ketika televisi pernah dipandang sebagai media di antara sejumlah saluran untuk menyampaikan ekspresi atau informasi, seharusnya televisi sudah dilihat sebagai elemen intrinsik dengan peran "laten" menentukan formasi budaya masyarakat. Perlu ditunjukkan bahwa televisi dalam berbagai konteks budaya terkait sifat budaya televisi dan bisa menjadi menjadi pokok kajian media televisi itu. Pekerjaan menggambarkan posisi wacana budaya televisi di dalam lingkungan masyarakat seiring dengan proyek menggambarkan lingkungan televisi itu. Karena dalam kasus pertunjukan langsung adalah kategori produksi budaya dipengaruhi oleh dominasi media, maka sangat penting untuk mengatasi situasi pertunjukan langsung dalam budaya mediasi (Auslander, 2008).

Menyelidiki budaya pertunjukan panggung saat ini, Philip Auslander dengan cepat menjadi tidak sabar dengan asumsi tradisional, dan tidak reflektif untuk melangkah lebih jauh dalam upaya menjelaskan nilai "kekuatan" pertunjukan panggung dan mistifikasi seperti "keajaiban teater panggung"; energi pementasan di antara para pemain dan penonton dalam sebuah pertunjukan langsung; komunitas pendukung ditampilkan pertunjukan langsung di antara para pemain dan penonton. Philip mengidentifikasi bahwa konsep-konsep magic dalam pertunjukan panggung memang memiliki nilai bagi pelaku seni dan pendukung pertunjukan langsung. Akan tetapi, konsepkonsep ini digunakan untuk menggambarkan hubungan antara kinerja live dan lingkungan 
termediasi saat ini, gabungan kerja itu menghasilkan oposisi biner reduktif dari seni pertunjukan dengan mediasi televisi.

In other words, if television once could be seen as ranking among a number of vehicles for conveying expression or information from which we could choose, we no longer have that choice: the televisual has become an intrinsic and determining element of our cultural formation. As Tony Fry indicates, it is indeed no longer a question of thinking about television in various cultural contexts but of seeing it as the cultural context. Clearly, this issue and the related question of the nature of television culture could be (and have been) the subjects of books in themselves (Auslander, 2008).

\section{The Five C's of Cinematography}

Buku tulisan Joseph V. Mascelli ini membahas teori dasarsinematografi. Kependekan kata menjadi lima 'C' dalam sinematografi yang dimaksud adalah camera angles, composition, continuity, close up, cutting (Joseph V. Mascelli., n.d.). Pemahaman dasar terhadap kaidah-kaidah sinematografi ini akan sangat penting bagi penayangan seni pertunjukan di layar televisi. Peneliti meyakini bahwa dalam memproduksi program acara televisi penerapan sinematografi menjadi ujung tombak segala perhitungan kualitas tayangan.

Mascelli mengungkapkan dalam bukunya, bahwa penempatan kamera merupakan penetapan sudut pandang penonton dalam mengamati objek. Oleh karena itu, penempatan kamera menjadi masalah mendasar agar hasil bidik yang didapatkan memberikan kesan alami sebagaimana penonton hadir langsung di tempat kejadian. Kamera yang ditempatkan secara benar dan penuh pertimbangan akan memberikan tampilan pencahayaan, blocking subjek gambar, sampai dengan komposisi subjek pada layar.
Penelitian ini menganalisis konsepkonsep dasar pengertian sinematografi dengan materi seni pertunjukan lengkap dari sisi materi seni, pelaku seni, pemanggungan, sampai dengan interaksi panggung dan penonton. Dalam satu sisi, pemahaman prinsip sinematografi sangat penting bagi pekerja kreatif media penyiaran, di sisi lain sangat diperlukan pemahaman mendalam terhadap objek sajian yang akan dikemas. Pergulatan kreatif dalam mengantisipasi sajian seni pertunjukan tradisional dalam proses produksi akan menjadi salah satu informasi penting dalam penelitian ini. Hal ini diyakini karena tidak banyak produk tayang seni pertunjukan tradisional berhasil menarik perhatian publik dan bahkan menjadi pilihan dalam pola rekreatif keseharian. Pemahaman seni pertunjukan secara sederhana haruslah mengetahui komponen di dalamnya, seperti materi seni, pelaku seni, penanggung jawab seni, penonton, sarana pendukung, manajemen pendukung, dan sumber dana pendukung kegiatan. Dari ketujuh komponen ini karakteristik seni pertunjukan dapat diperhitungkan keberadaannya.

\section{Cinematography}

Paul Wheeler adalah seorang tokoh, praktisi yang berpengalaman luas dalam dunia kreatif film dan televisi. Sebagai anggota British Society of Cinematographers (BSC), anggota Guild of British Camera Technicians (GBCT) dan British Kinematograph, Sound and television Society (FBKS), dia telah cukup banyak menulis buku. Paul Wheeler menulis ulang High Definition Cinematography dalam edisi ketiga. Hal ini berarti bahwa buku ini cukup memberikan manfaat dan pencerahan para penggunanya. Kutipan pendahuluan buku yang sangat menarik untuk dicermati dari Paul: 
Buku ini membahas multi camera shots, display quality, picture quality. Tiga informasi ini sangat penting untuk penelitian ini. Seperti pengalaman yang dituliskan, bahwa kualitas gambar biasanya sangat tajam dengan range tonal yang panjang, dan warna alami sebagaimana yang terlihat di monitor atau diprojeksikan secara digital. Kualitas gambar bagus ketika tidak ada scratching, gambar stabil dan sesuai dengan tuntutan script. Untuk memiliki standar kualitas yang tinggi, filter defusi dapat digunakan untuk mengurangi derajat kerusakan gambar akibat warna yang terlalu tajam (Wheeler, 2009).

Penelitian ini akan membahas kinerja director of photography, pengarahan acara. Apa yang harus disadari seseorang pada saat bertindak sebagai director of photography? Buku ini merumuskan, pertama, kepercayaan untuk bekerja sebagai director of photography berarti memiliki kesempatan untuk menunjukkan kualitas kreatif dengan pekerjaan baru. Kedua, untuk karya televisi, perlu meningkatkan kualitas gambar agar pada masa yang akan datang bisa dipakai untuk kontribusi di beberapa televisi yang berbeda. Hal ini memiliki risiko sedikit menaikkan anggaran produksi. Ketiga, jika produser program cukup lentur untuk team kreatif yang dilibatkan, merupakan kesempatan untuk memilih personel yang akrap dan memiliki kualitas kerja teruji. Keempat, dengan pekerjaan yang dipercayakan, memberi kesempatan untuk menempatkan diri sebagai pekerja kreatif yang semakin produktif.

Buku ini juga memberikan pelajaran mengenai teknik meningkatkan kualitas shot mapan; memberikan anjuran untuk menyediakan stok rekaman lebih banyak daripada yang diperlukan, dan teknik mengelola kamera. Secara lengkap buku ini memberikan penjelasan mengenai aspek komposisi yang mencakup framing, angle and moves, lighting, dan rules of thumb. Buku ini juga mendeskripsikan aspek continuity untuk dapat diterapkan langsung sebagai bahan pembanding pada saat mencermati buku rujukan lainnya.

\section{Television Studies}

Salah satu topik menarik dalam sisi akademik bidang penelitian televisi adalah mencermati hubungan interaktif antara penonton dan televisi. Dalam penelitian ini hubungan interasi ditempatkan sebagai fakta sosiobudaya, bahwa televisi memiliki domain cultural sangat penting jika dipahami pengaruh televisi cukup besar dan dapat memberikan wacana pada dunia realitas kehidupan yang sangat bertolak belakang dengan kehidupan penonton. Fokus terhadap impresi penonton saat mengikuti tayangan seni pertunjukan tradisional dapat digolongkan sebagai salah satu pemahaman tradisi konvergensi penelitian.

Buku yang ditulis oleh Bernadette Casey (Casey, 2008), berjudul Television Studies: The Key Concepts sangat menarik dan inspiratif terhadap arah pengelolaan penelitian ini. Buku ini dimaksudkan sebagai peta studi televisi, yang mengandaikan isinya sebagai peta territorial mengindikasikan model-model studi televisi.

\section{Teori Budaya}

Buku teks yang ditulis oleh David Kaplan dan Robert A. Manners (Manners, 2002) tentang teori antropologi dengan judul Teori Budaya cukup menarik untuk dijadikan rujukan penelitian ini. Penelitian seharusnya melibatkan interpretasi atas budaya tradisional masyarakat oleh sekelompok pekerja kreatif media penyiaran merupakan salah satu lahan analisis antropologi. Meski demikian, dari sisi sosiobudaya, peneliti tidak berpretensi masuk terlalu jauh dalam analisis yang bersifat 
antropologis. Bahkan secara tegas penelitian ini ingin lebih berfokus pada teknis kreatif dalam mengemas seni pertunjukan tradisional dengan mencermati berbagai model sinematografi yang sudah dilakukan oleh beberapa lembaga penyiaran perpilih.

Pemahaman terhadap beberapa penjelasan mengenai teori kebudayaan telah dibahas, sangat membantu peneliti untuk lebih hati-hati melihat fenomena di ranah kognitif, dan afektif persoalan sinematografi seni pertunjukan tradisional. Hal menarik untuk dipahami lebih dalam dari buku ini antara lain:

1. disiplin ilmu antropologi memiliki kekayaan orientasi teoretik dapat dirunut secara jelas. Oleh sebab keunggulan ini, peneliti terpanggil untuk dapat menerapkan salah satu teori titik pijak dialektikal antara seni pertunjukan dengan seni media penyiaran.

2. alternatif untuk menerapkan analisis formal baik dalam strukturalime maupun dalam pendekatan fenomena budaya akan sangat bermanfaat untuk menjembatani dialog kreatif antara seniman panggung dan pekerja kreatif media.

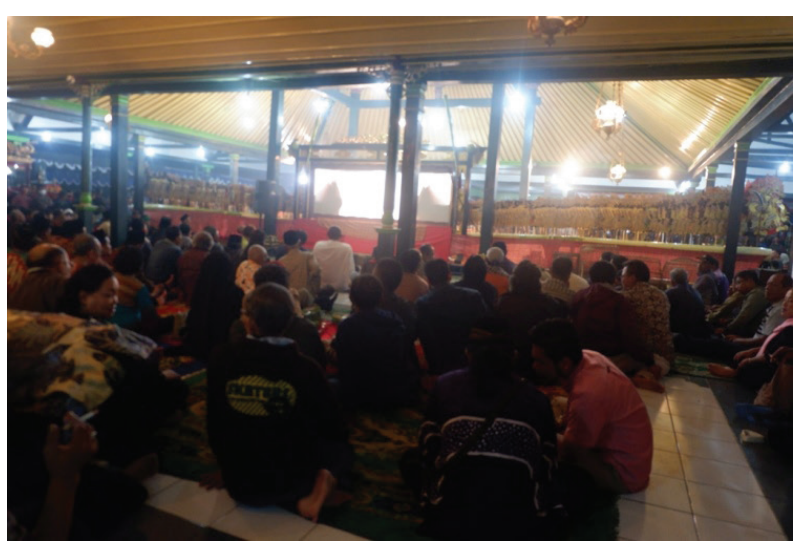

Gambar 7 Pergelaran wayang kulit di Dalem Yudonegaran Yogyakarta, dengan lakon Pendowo Boyong, oleh Dalang Seno Nugroho. Dokumentasi pribadi AE Suprihono, 2019.

\section{Kerangka Teori}

Pengkajian seni pertunjukan tradisional Indonesia merujuk pada model pemikiran, penempatan komponen pembentuk seni pertunjukan dengan dua wilayah sistemal, yakni domain estetika dan domain sosiobudaya lingkungan masyarakat (Tester, 2003). Ranah estetika mendeskripsikan berbagai persoalan internal sistem produksi seni pertunjukan dengan komponen pembentuk sebagai penentu tingkat kualitas dan kuantitas pertunjukan panggung. Berbagai irisan ketujuh komponen akan mengeksplorasikan tingkat interaksi etik dan estetik pergelaran dalam momen-momen panggung. Dari sisi sosiobudaya (Tester, 2003) dapat dipetakan persoalan-persoalan kemasyarakatan, seperti dominasi nilai ekonomi, potensi intervensi kekuasaan, dan bahkan kebutuhan hegemoni media. Jika komponen seni pertunjukan dibaca dari sisi eksternal ini, terbentang persoalan sosial kemasyarakat dengan alur diakronikal kausalitas eksistensi kegiatan pementasan. Potensi media dengan pesona diseminasi demografis dan geografis yang tidak berbatas memberikan indikasi adanya pokokpokok acuan liberalisasi baru seni pertunjukan di masyarakat. Wujud intervensi kuasa media menjadi layak dipertimbangkan dalam membentuk dimensi estetis seni pertunjukan.

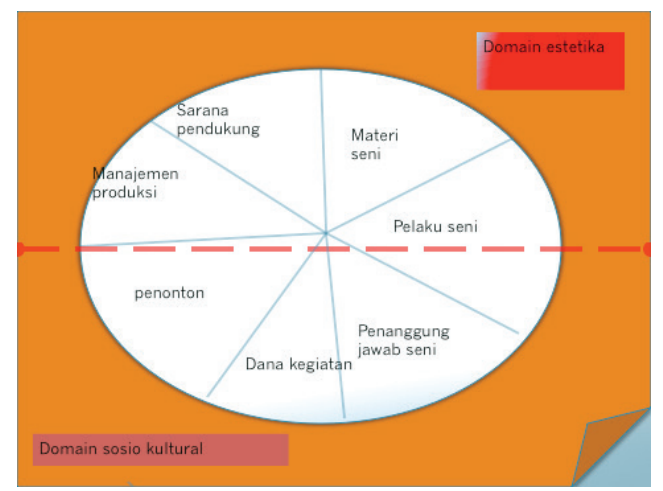

Gambar 8 Konstruksi komponen seni pertunjukan tradisional dalam bingkai domain estetika dan domain sosiobudaya (Suprihono, 2014). 
Ada tujuh komponen pendukung dalam setiap kegiatan pementasan seni pertunjukan, yakni materi seni, pelaku seni, penanggungjawab seni, dana kegiatan, penonton, manajemen produksi, dan sarana produksi. Komponen ini membentuk sebuah system kerja dan masing-masing menentukan model pertunjukan. Komponen dana kegiatan menjadi unsur penentu sifat seni pertunjukan. Setidaknya di masyarakat dikenali dengan dana kegiatan berasal dari pemerintah (government support); dana kegiatan berasal dari masyarakat (communal support); dana kegiatan berasal dari 'pasar' (commercial support). Pertunjukan bersifat komersial akan melibatkan dana kegiatan berasal dari jenis dukungan 'pasar'. (Arif Eko Suprihono, 2011, pp. 31-34)

\section{METODE PENELITIAN}

Proses kerja penelitian untuk menjawab pertanyaan-pertanyaan pengarah dilakukan dengan urutan sebagai berikut: formulasi masalah penelitian, penetapan sumber data, pengumpulan data, analisis data, pengolahan hasil analisis, penyimpulan temuan penelitian. Focus persoalan "transmedia seni pertunjukan tradisional dalam program tayangan televisi" mengarah pada produk kreatif pekerja televisi dalam mengemas sajian seni panggung pertunjukan wayang menjadi program tayangan. Kompleksitas teknis cinematografi merujuk pada upaya mengreasikan tayangan televisi untuk tetap menjaga estetika panggung pertunjukan dan mengembangkan potensi kamera dalam wujud bingkai tayangan. Tolok ukur keberhasilan transmedia panggung menjadi program tayangan antara lain terletak pada:

1. Kekuatan produk program dalam mengikat perhatian penonton mencermati hasil kreativitas tayangan;

2. Tingkat pemanfaatan potensi peralatan sinematik dalam mengubah wujudkan panggung pertunjukan dalam bingkai gambar dan dinamika editing sesuai dengan tuntutan estetika pergelaran panggung.

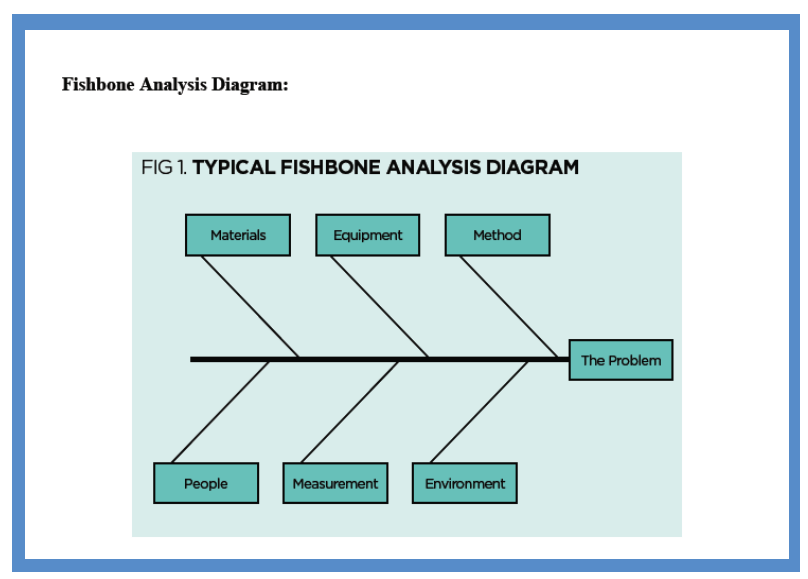




\begin{tabular}{|c|c|}
\hline $\begin{array}{r}\text { PERSO } \\
\text { PERTU } \\
\text { DALAM PRC }\end{array}$ & $\begin{array}{l}\text { N TRANSMEDIA SENI } \\
\text { KAN TRADISIONAL } \\
\text { AM TAYANGAN TELEVISI }\end{array}$ \\
\hline & $\begin{array}{l}\text { Dokumen program tayang } \\
\text { wayang kulit Jawa di televisi; }\end{array}$ \\
\hline MATERIAL & $\begin{array}{l}\text { Dokumen pementasan wayang } \\
\text { kulit Jawa di masyarakat; }\end{array}$ \\
\hline & $\begin{array}{l}\text { Dokumen audio wayang kulit } \\
\text { Jawa; }\end{array}$ \\
\hline $\begin{array}{l}\text { Tahap pekerjaan pe } \\
\text { sejumlah data tay } \\
\text { siaran televisi n } \\
\text { Materi data juga d } \\
\text { live streaming p } \\
\text { pertunjukan di } \mathrm{n} \\
\text { terjangkau dan ter } \\
\text { estetika social di wi } \\
\text { Data audio ditemı } \\
\text { pelaku seni, Ki H } \\
\text { Timbul Hadiprayit }\end{array}$ & $\begin{array}{l}\text { elitian ini ditemukan di lapangan } \\
\text { gan wayang kulit baik dalam } \\
\text { ional, maupun televisi local. } \\
\text { apatkan dalam sebaran tayangan } \\
\text { gelaran wayang. Dokumentasi } \\
\text { syarakat dipakai sebagai data } \\
\text { lih pada saat peneliti memasuki } \\
\text { yah Daerah Istimewa Yogyakarta. } \\
\text { an dalam cukup banyak variasi } \\
\text { di Sugito, Ki Narto Sabdo, Ki } \\
\text {, Ki Anom Suroto. }\end{array}$ \\
\hline & $\begin{array}{l}\text { Pendapat penonton wayang kulit } \\
\text { Jawa; }\end{array}$ \\
\hline & $\begin{array}{l}\text { Praktisi pelaku pementasan } \\
\text { wayang kulit Jawa; }\end{array}$ \\
\hline & $\begin{array}{l}\text { Kajian teoretik transmedia seni } \\
\text { panggung dalam seni media; }\end{array}$ \\
\hline & $\begin{array}{l}\text { Kajian kultural interaksi publik } \\
\text { dan produk kreatif media baru. }\end{array}$ \\
\hline $\begin{array}{l}\text { Penetapan opini } \\
\text { dimaksudkan untı } \\
\text { penonton tayanga } \\
\text { live streaming. Pe } \\
\text { dikaitkan dengan } \\
\text { wayang kulit deng }\end{array}$ & $\begin{array}{l}\text { ublic dalam penelitian ini } \\
\text { hengukur secara acak perhatian } \\
\text { ayang kulit di televisi maupun } \\
\text { pat masyarakat akan senantiasa } \\
\text { litas sinamatografi pertunjukan } \\
\text { misi estetika teknik sinematik. }\end{array}$ \\
\hline METHOD & $\begin{array}{l}\text { Pencermatan produk tayang } \\
\text { auditif visual, pengamatan } \\
\text { pertunjukan langsung, dan } \\
\text { penayangan materi siar di media } \\
\text { elektronik. }\end{array}$ \\
\hline PEOPLE & $\begin{array}{lcr}\text { Sebanyak } & \text { mungkin } & \text { masyarakat } \\
\text { Indonesia } & \text { dapat } & \text { mengetahui } \\
\text { informasi } & \text { solutif } & \text { persoalan } \\
\text { bangsa. } & & \end{array}$ \\
\hline MEASUREMENT & $\begin{array}{l}\text { Potensi trans media dalam } \\
\text { bentuk penyajian wayang kulit } \\
\text { Jawa dan adegan jejeran di } \\
\text { berbagai momen pertunjukan } \\
\text { dan penayangan program televisi }\end{array}$ \\
\hline
\end{tabular}

Ditemukenali ada tiga jenis potensi sinematografi dalam pertunjukan wayang kulit di masyarakat. Hal ini disebut sebagai potensi sinematografi dengan alasan esensi visualitas materi seni wayang kulit dalam mengelola perhatian penonton.

1. Potensi sinematografi dalam pergelaran wayang kulit dilakukan oleh dalang pada banyak adegan, seperti narasi dalam jejeran dengan mendeskripsikan tokoh, suasana, lingkungan, dan suasana adegan. Dalang dalam mempertunjukan estetika panggung mengeskplorasi dengan sangat cermat gerakan wayang berfokus pada posisi sumber cahaya (blencong) untuk menciptakan framing visual zoom in ataupun zoom out atas figure wayang di layar putih. Gerakan-gerakan figure wayang dimaksudkan sebagai animasi dan motion picture panggung wayang.

2. Potensi sinematografi dalam mengubah panggung pertunjukan menjadi program tayang, dilakukan oleh para pekerja media rekam dalam menempatkan kamera, memilih framing, dan menempatkan editing gambar. Potensi sinematik ini menunjukkan relasi kuasa dalam mengubah dan menyesuaikan model setting pertunjukan tradisional wayang kulit dalam hasil akhir tayangan televisi. Ada banyak tindakan kreatif para pekerja media menjadikan produk tayangan sebagai hibriditas kompleks bagi otentisitas panggung pertunjukan.

3. Potensi sinematografi dalam menikmati pertunjukan wayang kulit panggung, dilakukan oleh penonton sebagai wujud interaksi keakrapan seni panggung dan masyarakat. Estetika social ini menjadi salah satu tolok ukur bagi penilaian kualitas transformasi kultural di peristiwa budaya wayang kulit.

\begin{tabular}{|l|l|}
\hline \multirow{2}{*}{ ENVIRONMENT } & $\begin{array}{l}\text { Kondisi budaya masyarakat dan } \\
\text { kompleksitas potensi estetis } \\
\text { pementasan wayang kulit. }\end{array}$ \\
\hline
\end{tabular}

Ditemukan data pertunjukan wayang kulit di masyarakat, bahwa penyelenggaraan pertunjukan masih didasarkan pada alasan kultural berbasis Upacara ritual, rutinitas rekreatif, ceremonial politik, dan komunikasi propaganda.

\section{PEMBAHASAN}

\section{Transkontekstualisasi dan Transformasi}

\section{Pemanggungan}

Persoalan utama proses trasformasi panggung ke layar televisi, pergelaran wayang kulit memiliki 'dialektika kreatif' antara pekerja seni panggung dengan tim kreatif pertelevisian. Perbedaan perspektif 'etika kerja' dua jenis pekerja seni mengarah pada kualitas formulasi sinematografi (Zettl, 2006). Dialektika utama difokuskan pada 
bagaimana menjaga konsistensi karakteristisik Seni Pertunjukan Tradisional (Mardimin, 1994) Indonesia harus diwujudnyatakan dalam tuntutan standar transformasi media, seperti camera angles, close up, cutting, continuity, compotition agar tampilan layar memiliki pemenuhan standar estetika media penyiaran. Dalam ketidakseimbangan posisi tawar pekerja seni pertunjukan dan pekerja media, televisi menunjukkan dominasi estetik atas pokok-pokok autentisitas pemanggungan seni pedalangan. Bentuk implementasi kuasa sinematografi dapat dilihat dalam bentuk bingkai sajian pergelaran wayang kulit, dan sebagai sebuah konsekuensi transformatif, para pekerja kreatif wayang kulit dapat ditempatkan dalam posisi sentral secara formal dalam panggung pergelaran.

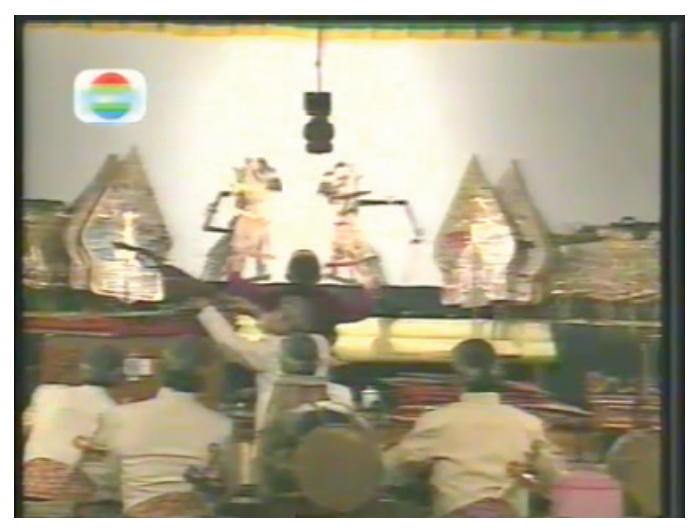

Gambar 9 Rekam pergelaran wayang kulit di Indosiar.

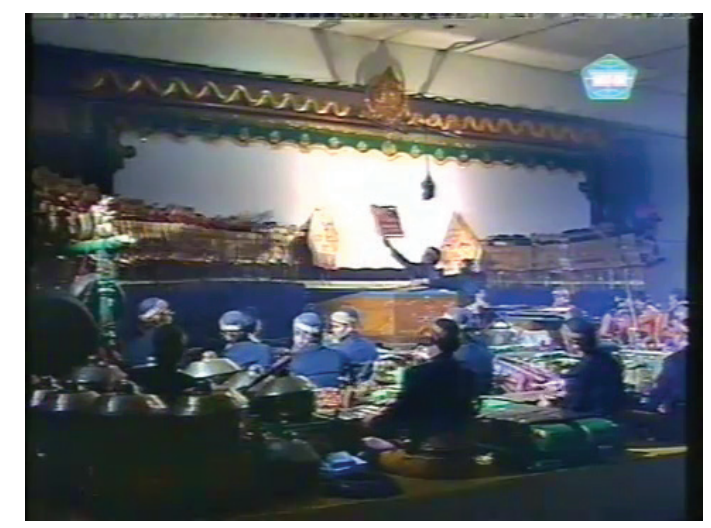

Gambar 10 Rekam pergelaran wayang kulit di Televisi Republik Indonesia.
Hibriditas produk pertunjukan wayang kulit dalam tayangan televisi menunjukkan terminologi estetika teknis pergelaran studio rekam. Wayang kulit dipandang sebagai rentang setting pementasan dengan kemungkinan banyak potensi framing atas kamera-kamera perekam. Dalam proses trasformasi wujud pementasan panggung menjadi program tayang televisi, di lapangan atau studio produksi, ditemukan setidaknya tiga kamera mengarahkan bidikan dengan floorplan berbeda. Sebagai sebuah setting pertunjukan, komunikasi dalang dan penyampaian bahasa bayang-bayang figure wayang tidak dapat ditemukan lagi dalam format siaran media, baik live streaming maupun live performance televisi. Judgment atas posisi kamera pada objek rekam pertunjukan wayang tidak akan mengacaukan sudut pandang penonton dengan melintas garis batas bidang rekaman. Relasi kuasa atas setting pertunjukan wayang kulit berdampak luas pada penyebaran model pertunjukan di masyarakat. Penonton tidak lagi mengenali pertunjukan wayang dengan melihat dari balik layar, menikmati keindahan bayang-bayang dan permainan imajinasi akibat pengelolaan blencong, tetapi sebagaimana wujud pementasan televisi memaksa penonton berkomunikasi dengan dalang secara proscenium.

\section{Potensi Sinematografi}

Istilah sinematografi berasal dari akar katabahasa Yunani berartimenulis dengan gerak. Pemahamannya bukan sebatas aspek fotografis, tetapi menukik pada proses pengungkapan gagasan, tindakan, emotional subtext, dari komunikasi nonverbal menyumbangkan pemahaman dalam bahasa visual. Oleh karena itu, teknik sinematik mencakup jangkauan luas cara dan teknik bagaimana kreativitas 
visual dapat mengantarkan content dari para pemain, setting, dialog, dan bahkan tindakan. Pemahaman ini menjadi penting karena ketika berkarya medium visual, seperti film, satu hal utama dalam pekerjaan ini adalah mengkreasikan dunia visual melalui berbagai potensi untuk dimengerti oleh penonton. Dunia visual itu merupakan satu bagian penting, bagaimana penonton akan memahami dan menerima uraian cerita dan bahkan bagaimana penonton mengerti karakter dan motivasi dari tayangan di depannya (Brown, 2016:2). Oleh karenanya, perlu dipikirkan bahwa bingkai gambar bukan sekadar wujud gambar, melainkan informasi jelas tentang berita. Penonton menerima berita dengan persepsi jelas di seluruh rangkaian gambar. Komposisi gambar akan mengarahkan perhatian penonton untuk bukan sebatas melihat, tetapi menerima pesan karena desain film akan bermuatan arahan perhatian penonton dan bagaimana memahami rangkaian berita tersampaikan. Dalam konteks inilah bagaimana point of view tayangan akan senantiasa mengungkapkan pesan visual dengan menarik dan penuh makna."An image should convey meaning, mode, tone, atmosphere, and subtext on its own-without regard to voiceover, dialog, audio, or other explanation" (Brown, 2016:14).

Ditemukan dan dikenali dengan baik, pertunjukan wayang kulit memiliki tiga potensi sinematografi. Potensi ini menunjuk pada muatan estetika dari berbagai sudut pandang pemahaman wayang kulit sebagai sajian pertunjukan tradisional dan modern.

1. Kreativitas dalang sebagai potensi sinematografi dalam pergelaran wayang kulit. Dalang sebagai pelaku dan penanggung jawab seni pertunjukan mengungkapkan banyak model narasi dalam jejeran dengan mendeskripsikan tokoh, suasana, lingkungan, dan suasana adegan. Dalang menguasai animasi dan estetika panggung melalui eskplorasi gerakan wayang berfokus pada posisi sumber cahaya (blencong) untuk menciptakan framing visual zoom in ataupun zoom out atas figure wayang di geber.

2. Kreativitas pekerja media rekam sebagai potensi sinematografi dalam mengubah panggung pertunjukan menjadi program tayang. Para pekerja media rekam membuat desain perekaman (shooting design) dengan menempatkan kamera, memilih framing, dan menempatkan editing gambar. Potensi sinematik bagi program director media rekam adalah wujud relasi kuasa dalam mengubah dan menyesuaikan model setting pertunjukan tradisional wayang kulit dalam hasil akhir tayangan televisi. Pekerjaan kreatif dari intervensi teknologi media rekam akan menjadikan produk tayangan sebagai hibriditas kompleks bagi otentisitas panggung pertunjukan

3. Kehadiran penonton sebagai potensi sinematografi dalam menikmati pertunjukan wayang kulit panggung. Estetika sosial ini menjadi salah satu tolok ukur bagi penilaian kualitas transformasi kultural dalam peristiwa budaya wayang kulit. Kebebasan penonton memilih tempat untuk hadir sebagai penikmat pertunjukan secara otomatis akan menempatkan perhatiannya sebagai kamera, memiliki kebebasan sudut pandang tanpa harus mempertimbangkan jumping shoot bagi apresiasi visual mereka. 


\section{SIMPULAN}

Persoalan teknik mengemas seni tradisi pementasan wayang kulit mensyaratkan pemahaman aspek sosiokultural masyarakat. Konteks penataan setting pertunjukan wayang, dari sisi kepentingan sinematografi televisi memerlukan respons kreatif para pelaku pertunjukan. Teknik simpingan wayang, teknik simpingan vokalis, teknik penataan instrumentasi gamelan, sampai dengan ukuran panggung, ukuran gedebog, ukuran geber, menjadi lebih besar dan megah. Di sisi lain, estetika sosial atas perubahan setting panggung pertunjukan, dalam tanggapan penonton menjadi berubah. Pemetaan temapat menonton wayang kulit tidak lagi leluasa bagi masyarakat. Sisi pandang penonton menjadi lebih terbatas pada posisi belakang pelaku pentas (dalang, pengrawit, dan gamelan).

Aspek penataan panggung menyiratkan fenomena transcontextualitation atas 'tradisi' atau pakem pergelaran wayang menjadi model pemanggungan baru. Dapat diinterpretasikan, dari posisi penonton di belakang dalang, mencerminkan pola sajian panggung proscenium, tempat penonton melihat dan melibatkan diri dari sisi depan pementasan. Meski jika dilihat dari sisi komunikasi objektif, penonton dan dalang tidak dalam posisi face to face, panggung berubah menjadi tontotan formal dengan berbagai pernik estetika komponen panggung, seperti simpingan wayang, posisi waranggana, dan posisi instrumentasi gamelan. Perubahan sifat teater total menjadi pertunjukan proscenium diikuti oleh posisi penonton wayang berada terbatas di bagian belakang dalang.

Perubahan setting panggung pergelaran wayang kulit menjadi indikasi persoalan hegemoni politik bisnis media televisi, dapat dimaknai sebagai wujud penetrasi ekonomi jika diidentifikasi dari factor authenticity pertunjukan. Persoalan pelestarian budaya lokal, jika harus dihadapkan dengan persoalan teknik cinematics akan menjadi persoalan liberalisasi baru budaya masyarakat.

\section{KEPUSTAKAAN}

Auslander, P. (2008). Liveness Performance in a Mediatized Culture. London \& New York: Roudledge.

Brown, B. (2016). Cinematography Theory and Practice Image Making for Cinematographer and Directors. London \& New York: Routledge.

Casey, B. (2008). Television Studies: The Key Concepts. London \& New York: Routledge.

Curran, J. (2002). Media and Power. New York: Routledge.

Hidayat, N. R. (2014). Nilai Estetik Film Opera Jawa. Rekam Jurnal Fotografi Televisi, 3. Joseph V. Mascelli. (n.d.). The Five C's of Cinematography. California: Cine/ Graphics Publication.

Manners, R. A. (2002). Teori Budaya. Yogyakarta: Pustaka Pelajar.

Mardimin, J. edt.(1994). Jangan Tangisi Tradisi: Transformasi Budaya Menuju Masyarakat Indonesia Modern. Yogyakarta: Kanisius. Naratama. (2004). Menjadi Sutradara Televisi. Jakarta: PT Gramedia.

Suprihono, A. E. (2007). Membaca Kompleksitas Fotografi Seni pertunjukan. Rekam Jurnal Fotografi Televisi, 2(1).

Suprihono, A. E. (2014). Cinematography Seni Pertunjukan Tradisional dalam Tayangan Televisi. Yogyakarta: BP ISI Yogyakarta. Tester, K. (2003). Media, Budaya dan Moralitas. Yogyakarta: Juxtapose. 
Jurnal Rekam, Vol. 15 No. 2 - Oktober 2019

Wheeler, P. (2009). High Definition Cinematography. Amsterdam: Focal Press. of Elsevier.

Zettl, H. (2006). Television Production Handbook, 9th edt. Belmont: San Francisco State University. 
